\title{
A cultura do encontro nas redes sociais
}

Marcylene de Oliveira Capper

Ao agradecer aos voluntários que ajudaram no sucesso da Jornada Mundial da Juventude (JMJ), em julho, na cidade do Rio de Janeiro, o Papa Francisco, em seu último dia no país, fez questão de destacar o que já tinha afirmado para os peregrinos do mundo inteiro durante todo o evento: "peço que se rebelem: que se rebelem contra esta cultura do provisório que, no fundo, crê que vocês não são capazes de assumir responsabilidades, crê que vocês não são capazes de amar de verdade. Eu tenho confiança em vocês, jovens, e rezo por vocês. Tenham a coragem de "ir contra a corrente". E tenham também a coragem de ser felizes!" 1

É a partir do desafio de abandonar a ação descartável, alimentada por muitos nos dias de hoje e, abraçando a proposta do Santo Padre por uma cultura do encontro com o próximo, que esta reflexão se insere. Aposta e tenta analisar a juventude que transgride em direção ao bem comum, utilizando ferramentas no espaço digital que lhe são familiares. Esse novo campo de atuação na internet, no que se refere inclusive à evangelização, passa a ser compreendido como terra fértil para encurtar distâncias, até mesmo ideológicas.

Para ajudar na abertura deste pensamento, foi fundamental a contribuição de Clay Shirky ${ }^{2}$, que analisou na rede virtual o poder de organizar sem organizações. A ação coletiva, cada vez mais rápida e eficaz, resulta - concordamos com o parecer desse autor - em uma consciência compartilhada, "o passo necessário para a verdadeira ação política".

Também muito interferiu na trajetória dessas anotações o campo da sociologia com R.Sennett ${ }^{3}$, quando abordou as consequências pessoais do trabalho no novo capitalismo, entendendo aqui trabalho de uma forma mais ampla.

É nossa intenção apontar o sucesso das redes sociais na disseminação de autênticos valores, que pareciam estar guardados na gaveta com o vazio ético que se instalou na era contemporânea. Fraternidade, dignidade e preocupação com o próximo e tantos outros, que denunciam o modo cristão de viver, surgem na esfera virtual, misturando crentes ou não crentes.

Apenas criticar a veracidade das informações no ambiente digital, por receber constantemente texto de amadores e, entender que 'quanto mais conteúdo autocriado é despejado na internet, mas difícil se torna distinguir o bom do ruim'4, não nos parece mais adequado. A celebração do amadorismo tornou-se moeda positiva. São bem vindas todas as produções que respeitem os fundamentos éticos e contemple o ser humano em toda a sua dimensão.

\footnotetext{
${ }^{1}$ Discurso Papa Francisco aos voluntários na JMJ Rio2013, Riocentro, 28.7.2013. Disponível em http://www.universitarioscristaos.com.br/images/PDF/Discursos PapaFrancisco JMJRio2013.pdf.

2 SHIRKY, C. Lá vem Todo Mundo. Rio de Janeiro: Zahar, 2012, p.140

${ }^{3}$ SENNETT, R. A corrosão do Caráter. Rio de Janeiro: Record,2011.2011

${ }^{4}$ KEEN, A. O culto do amador.Rio de Janeiro: Zahar,2009, p.33
} 
A rede, da mesma forma que a Igreja, a todos acolhe, reconhece talentos, prontos para serem aproveitados, e na verdade soma esses esforços, contrariando alguns 'militantes' da mídia.

\section{$\underline{\text { Todos juntos somos fortes }}$}

A dinâmica de viver em rede, comum na juventude, coincide, em parte, com a proposta de trabalhar em equipe nos dias de hoje, que se traduz, de fato, em uma ação individualista, já denunciada por Sennett, quando analisou a mudança da moderna estrutura institucional para ações flexíveis, nas quais não existe longo prazo e "empregos tornaram-se projetos" 5 . Desta forma, abre-se espaço para o perigo de relacionamentos curtos e descartáveis, sem a possibilidade de aprofundar laços, algo tão necessário ao conhecimento do outro.

A surpresa fica por conta de jovens internautas que surgem como verdadeiros protagonistas do futuro e não só apostam em ampliar amizades, mas também usam o campo "minado" da internet para semear tolerância, no sentido amplo da palavra, isto é, respeitando diferenças e acolhendo e compartilhando saberes.

Não faltam exemplos nas plataformas digitais mais comuns, como blogs, entre outros, de jovens que utilizam essas ferramentas como um canal de "afirmação da fé", unindo plataformas diferenciadas, que não serão aprofundadas neste esboço, mas merecem ser observados. As opções e preferências da juventude nas redes sociais, reunindo gostos e situações adversas, precisam ser consideradas, inclusive por aqueles que não conseguem 'botar fé' nesse público.

É comum encontrar nesses ambientes, mensagens que mesclam atitudes diferenciadas, abertas, sinalizando que não há barreiras nem preconceitos. Foi possível observar nos compartilhamentos, apenas durante a semana da Jornada Mundial da Juventude, de 23 a 28 de julho de 2013, uma avalanche de mensagens originárias de fontes diversas, que pregavam o respeito e a dignidade.

A proposta inicial desta pesquisa é aguçar no leitor o desejo de mergulhar na rede em perfis distintos, que deixam transparecer a beleza do ser humano ao lidar delicadamente com o seu próximo, amador em sua produção, mas o retrato fiel da obra de Deus.

Percebemos que estes 'novos marinheiros' navegam em uma verdadeira 'onda do bem', aquela que se instalou na cidade, como o próprio prefeito Eduardo Paes ${ }^{6}$ definiu ao falar atônito aos jornalistas, quando percebeu que os jovens invadiram a cidade em uma corrente de fraternidade e paz. E presenciamos no ambiente digital, cada vez mais, uma proliferação de pessoas que pregam valores até então ignorados ou até mesmo em desuso.

\footnotetext{
${ }^{5}$ SENNETT. R., op. cit., p.115

${ }^{6}$ Coletiva de imprensa, 27.7.2013, Media Center- Forte de Copacabana
} 
A cultura do encontro e do relacionamento, tão defendida pelo Papa Francisco ao falar com a sociedade brasileira ${ }^{7}$, mostra com estas atitudes o modo cristão de promover o bem comum. Arrisco dizer que não é outra coisa senão a manifestação do Divino que penetra, através dessas pessoas, no ambiente cibernético e contamina como um vírus que não corrói, mas pelo contrário, trás à tona nobres valores. Sorte que a Igreja, embora tardiamente, percebeu a urgente necessidade de ocupar esses espaços para cumprir a sua missão: promover o homem em toda a sua dimensão.

Uma conclusão preliminar aponta para a necessidade de compartilhar, conforme manda a linguagem da rede social, mensagens e atitudes de solidariedade que proliferam neste ambiente, algo que, para alguns autores ${ }^{8}$, ainda são sinônimos de solidão, falta de privacidade e egoísmo. Não negamos que todas as plataformas de redes sociais são como lembrou Spadaro "um conjunto de ajuda potencial para as relações e uma ameaça própria", que é inegável não esquecer que nada substitui uma relação direta, "conexão não é necessariamente comunhão".

O que se pede é um novo olhar, atento e mais profundo na produção de conteúdos na web por esse público. Enquanto parte da academia fala em 'isolamento' e 'conexão obsessiva', percebemos, ao contrário, grupos de jovens capazes de amar o próximo, como já aprendemos na lição deixada por Francisco, dispostos sim, a pregar a fraternidade, caminho para uma verdadeira paz. Acreditamos que a palavra-chave do momento é 'humildade'. A cultura do encontro nas redes sociais é, não só possível, como real.

\section{Para refletir:}

1- Alguns autores percebem as redes sociais, apenas como um grande depositário de informações, que alimenta a falta de reflexão. O que, de fato, a internet está fazendo com os nossos cérebros afinal?

2- Vale questionar ainda como será possível viver "a cultura do encontro" hoje quando, em determinadas situações, percebemos uma sociedade que prega justamente o contrário?

\section{Bibliografia:}

KEEN, Andrew. O culto do amador. Rio de Janeiro: Zahar,2009.

\#Vertigem Digital. Rio de Janeiro:Zahar,2012.

SENNETT, Richard. A corrosão do Caráter. Rio de Janeiro: Record,2011.

SHIRKY, Clay. Lá vem Todo Mundo. Rio de Janeiro: Zahar, 2012.

SPADARO, Antonio. Ciberteologia, Pensar o Cristianismo em tempos de Rede. São Paulo:Paulinas,2012.

\footnotetext{
${ }^{7}$ Encontro com os Representantes da Sociedade Civil, Theatro Municipal, dia 27.7.2013. Disponível em: http://www.universitarioscristaos.com.br/images/PDF/Discursos PapaFrancisco JMJRio2013.pdf.

${ }^{8}$ Ver KEEN,A. Vertigem Digital. Rio de Janeiro:Zahar,2012, p.19

${ }^{9}$ SPADARO.A. Ciberteologia, Pensar o Cristianismo em tempos de Rede. São Paulo:Paulinas,2012, p.61
} 